\title{
DATING THE CRATONIC LOWER CRUST BY THE ION MICROPROBE SHRIMP: AN U-Th-Pb ISOTOPIC STUDY ON ZIRCONS FROM LOWER CRUSTAL XENOLITHS FROM KIMBERLITE PIPES.
}

\author{
Chen, ${ }^{(1)}$ Y. D.; O'Reilly, ${ }^{(1)}$ S.Y. and Kinny ${ }^{(2)}$ P.D.
}

(1) School of Earth Sciences, Macquarie University, Sydney, NSW, 2109, Australia. (2) Research School of Earth Sciences, The Austraslian National University, Canberra, ACT, 2601, Australia.

We here report an U-Th-Pb isotopic study of zircons from a suite of lower crustal (probably also upper mantle) xenoliths from some kimberlitic pipes at Calcutteroo, South Australia by using the ion microprobe SHRIMP at Research School of Earth Sciences of The Australian National University. In particular, zircons from a xenolith of eclogitic composition were first time found and dated.

Xenoliths found from the Calcutteroo kimberlitic pipes include spinel lherzolite, eclogite, mafic and quartzo-feldspathic granulites with the mafic granulite predominant. The importance of these xenoliths is that they are extremely rare occurrence of samples of lower crust and upper mantle from a tectonic environment of eastern margin of the Australian Craton. Petrological, geothermobarometric and geochemical studies on these xenoliths (Pearson et al., 1991) have resulted in information on the composition and stratigraphy of the lower crust and upper mantle of the region but not the timing. Seven mafic to felsic granulite xenoliths were previously dated by whole-rock $\mathrm{Rb} / \mathrm{Sr}$ and $\mathrm{Sm} / \mathrm{Nd}$ techniques (McCulloch et al., 1982). On the assumption that these xenoliths were petrogenetically coherent and recorded a major intracrustal differentiation event, an age of $2400 \mathrm{Ma}$ was suggested from the whole-rock isochron. In the present study, we separated and dated zircons from three xenolith types: eclogite (1 xenolith), mafic (1 xenolith) and quartzo-feldspathic (3 xenoliths) granulites.

Zircons from the three quartzo-feldspathic granulite xenoliths gave bimodal age distribution: 1700-1500 Ma and 600-350 Ma. Zircons from the mafic granulite xenolith have ages mostly clustered between 800 and $700 \mathrm{Ma}$ with subordinate number of spot analyses being younger (530-480 Ma). Zircons from the eclogite xenolith range in age from 600 to $300 \mathrm{Ma}$. The immediate significance of these zircon growth ages is that they invalidate the previous $\mathrm{Rb} / \mathrm{Sr}$ and $\mathrm{Sm} / \mathrm{Nd}$ isochron ages. It is shown that the different types of xenoliths were not co-genetic and therefore a whole-rock isochron age is not meaningful.

More importantly, the zircon data indicate that the formation of lower crust (also upper mantle) of the region is the result of multiple-episodes. The 1700-1500 Ma age of the zircons found from the quartzo-feldspathic granulite xenoliths broadly coincides with the development duration of the Willyama metamorphic complex occurring in South Australia and New South Wales; this indicates that the distribution of Willyama complex is more extensive than presently exposed and is southwards extended to beneath the region of Calcutteroo. The different, younger ages found in all xenolith types indicate that several later episodes of mantle-derived magma intrusion and regional metamorphism have occurred in the region and significantly contributed to the growth and evolution of the lower crust.

\section{REFERENCES}

McCulloch, M.T., Arculus, R.J., Chappell, B.W., and Ferguson, J. (1982) Lower continental crust: inference from isotopic and geochemical studies on nodules in kimberlites. Nature, 300, 166-169.

Pearson, N.J., O'Reilly, S.Y., and Griffin, W.L. (1991) The granulite to eclogite transition beneath the eastern margin of the Australian craton. European Journal of Mineralogy, in press. 